\title{
Storying music and the arts education: the generalist teacher voice
}

\author{
Susanne Garvis ${ }^{1}$ and Donna Pendergast ${ }^{2}$ \\ ${ }^{1}$ University of Queensland, School of Music, St Lucia, Queensland, Australia \\ ${ }^{2}$ Griffith University, School of Education and Professional Studies, Mt Gravatt, Queensland, Australia \\ s.garvis@uq.edu.au, d.pendergast@griffith.edu.au
}

For students in Years 1-10 in Queensland, Australia, The Arts (hereafter referred to as 'arts') is one of eight Key Learning Areas in the core curriculum. Yet, while arts - comprising five strands including music - is a mandatory component of the curriculum, implementation varies widely. This occurs for a range of reasons, one of which is the common practice that generalist teachers are allocated delivery of the arts programme in their teaching load. Furthermore, research reveals that music and the arts are frequently considered to be the 'frills subject' in a school's timetable, often the first to be removed from the timetable when time is short and the first to feel the impact of budget cuts, including the engagement of specialist arts educators (Russell-Bowie, 2004). This study highlights the gap between policy rhetoric for music and the arts and the pedagogical reality in generalist classrooms. Using a narrative informed case study methodology, a story constellation derived from a beginning generalist teacher and a school principal is revealed. The discussion which follows provides a focus, through the generation of key values statements derived from the data, on the tensions this beginning teacher has experienced in his practice as a teacher responsible for teaching music and the arts, juxtaposed with a similar narrative of the school principal.

\section{Introduction}

In Queensland, Australia, arts education is a key learning area endorsed in the Hobart Declaration (Ministerial Council on Employment, Education, Training and Youth Affairs, hereafter referred to as 'MCEETYA', 1988) and more recently in the National Education and the Arts Statement (MCEETYA, 2005). It is comprised of five strands: music, drama, dance, visual arts and media. Although it is a core, specialist area of the curriculum, it is common practice for generalist teachers to deliver the arts curriculum for students in the early and middle years. However, this reliance on generalist teachers to deliver specialist curriculum is recognised as being problematic. Research in Australia (Russell-Bowie, 1993, 2004) and around the world (Hennessy et al., 2001; Oreck, 2001, 2004; Smithrim \& Upitis, 2001; Upitis et al., 1999) confirms that generalist teachers delivering arts education often grapple with challenges including a lack of confidence, motivation and knowledge to deliver the

\section{CAMBRIDGE JDURNALS}


curriculum successfully. Their capacity to undertake the role effectively is dependent upon a range of factors, including: their own beliefs about their competence; the school context; pressures of the curriculum; and expected benefits for students. For those teachers unable to cope with the challenges of delivering a relatively unfamiliar curriculum, it is typical for them to allocate less time to the in-class teaching and learning experiences in which their students engage. The result is fewer pedagogical opportunities for students in the arts, including music education.

Bamford (2007), along with others (Russell-Bowie, 1993, 2004; Garvis \& Pendergast, 2010) is critical of this scenario, linking it directly to inadequate funding and support for music and the arts in schools. She notes that while the arts appear in the educational policy in almost every country in the world "there is a gulf between the lip service given to arts education in the provision... within schools" (Bamford, 2007, p. 48). This is similarly confirmed by Winner (2007, p. 25) who complains that the arts have been "trivialised within our education system". The gap between policy rhetoric and pedagogical reality is well documented and lamented by researchers in music and arts education.

\section{A short history of arts education in Australia}

Over the past 35 years in Australia, several inquires have been conducted investigating various aspects of arts education, including the quality of arts education experiences of teachers and students occurring in schools (see New South Wales Ministry of Education, 1974; Schools Commission/ Australia Council, 1977). These reports reveal similar findings about the scarcity of Arts education occurring in schools.

In 1995, the Australian Senate Inquiry into Arts Education (1995) investigated arts teacher education training for generalist teachers, noting that the teaching of arts education in school was typically pushed to the periphery because of inadequate teacher in-service training and professional development and a lack of confidence by generalist teachers to teach the arts, "creating a strong impulse to marginalise the Arts in their teaching" (1995, p. 49). The inquiry drew parallels between amateur participation in sports and participation in the arts, stating:

"[M]any mentioned the wider good of people 'participating' in the Arts or 'appreciating' the Arts ... few tried to define these terms of discussed their implications. Few discussed the place of a widespread amateur creative life in adult happiness. The situation contrasts interestingly with the position of physical education, where it is widely accepted that being physically active is a fundamental good and something that everyone should do throughout life" (Senate Inquiry, 1995, p. 14).

The inquiry recommended improvements to the: the monitoring of curriculum change; implementation of professional development programmes; and the need to increase the number of specialist teachers available to primary schools. Fifteen years on, many of these recommendations have not been implemented, with current research similarly reporting the low status of arts and music in the schooling curriculum (Stevens, 2000).

With mounting concern that music education in Australia was approaching a crisis, in 2005 a National Review of School Music Education was conducted. The Review reinforced 
earlier findings from the Senate Inquiry, highlighting the need for improvement of all preservice teacher education for specialist primary and secondary teachers. It acknowledged that the cycle of neglect highlighted in the Senate Inquiry (1995) still continued, typified by: a lack of continuity in teachers' own experiences in the Arts; cutbacks in teacher education; a lack of support from school administration; declining centralized curriculum support; declining use of primary specialist teachers; and devolution of decision-making to schools (Senate Inquiry, 1995).

The Review established a pattern of decline in the hours allocated to generalist primary pre-service education courses for developing capabilities for the teaching of music and arts in schools (Department of Education, Science and Training and Centre for Learning Change and Development, 2005). Previous research has shown that on average, pre-service teachers receive only 23 hours of music training in their entire teacher education (Music Council Australia, 2003). The Review (2005, p. xvi) recommended that for improved music teacher education:

- The Australian Government should explore ways to encourage universities (and other providers of teachers education) to provide more time for Music education for preservice teachers (p. xvi).

- Universities and Schools of Education should enhance or transform courses for generalist classroom teachers to ensure that there is dedicated time to Music education and that student teachers develop and demonstrate knowledge, understanding and skills in their own Music making as well as teaching Music (p. xvi).

- Graduating and beginning teachers should demonstrate the currency and relevance of their knowledge, understanding, skills and values about Music education (p. xvixvii).

The expectation of music and arts education in schools was again made public by the Australian Ministerial Council on Education Employment, Training and Youth Affairs (MCEEYTA) releasing a statement entitled the National Education and the Arts Statement (2007). Building from the Adelaide Declaration on National Goals for Schooling in the Twenty-First Century (1999), this statement was designed to foster a culture of creativity and innovation in Australian schools. It acknowledged that an education rich in the creative arts maximises opportunities for learners to engage as innovative thinkers and learners, emphasising not only creativity and innovation, but also the values of broad cultural understandings and social harmony that the arts can engender. This is empathic to United Nations Educational, Scientific and Cultural Organisation's Road Map for Arts Education (2006), with arts considered a necessity for skill development in the 21 st century, allowing nations to develop the human resources necessary to tap their cultural capital. Three key principles underpinned the statement to drive change by laying a foundation for stronger co-ordination between educational institutions and also to guide arts and education leaders to ensure that the Australian education system helps children and young people to achieve. These were (2005, p. 5):

- All children and young people should have a high quality arts education in every phase of learning; 
- Creating partnerships strengthens community identity and local cultures; and

- Connecting schools with the arts and cultural sector enriches learning outcomes.

In particular, it acknowledged that arts experiences enhance all phases of schooling. All students, irrespective of their location, socio-economic status or ability should have equal opportunities to participate in arts-rich schooling systems (MCEETYA, 2005). School-based arts experiences should be diverse, based on models of effective practice, and embedded from the early years through to graduation in order to unlock the creative potential of young people (MCEETYA, 2005). In order to foster this crucial change in arts education, the statement acknowledges the necessity to foster the skills and knowledge of teachers through pre-service training and professional development.

\section{The current study}

It is within this wider contextual milieu, characterised by a vast gap between the rhetoric of music and arts education as presented from a policy position; and the lived classroom experiences of teachers and students, that the research reported in this paper was conducted. It has engaged with two of the key elements of what might be regarded as a crisis in music and the arts in school education: it includes a focus on a generalist beginning ${ }^{1}$ teacher responsible for delivering the music and arts curriculum; and it includes a school where arts education has been 'pushed to the margins'. This paper reports on the implementation and practice of music and arts teaching from the voice of one generalist teacher and one principal in a Queensland school (Australia). Using a story constellation narrative approach, divergent accounts of practice in music and arts education begin to emerge, revealing the tensions and challenges the teacher and principal experience in their practice as educators and teaching professionals.

\section{Methodological approach}

The narrative informed case study reported in this paper is one of four that collectively inform a doctoral study investigating beginning generalist teacher self-efficacy for arts and music education (see Garvis, 2010). This case study is a Catholic primary school in a metropolitan area outside of Brisbane. The school is located in a low socio-economic area and has a reputation for catering for the special needs of students. It was included in the study after the beginning generalist teacher participated in an online survey and indicated a willingness to be used as a case study site. In this case study, Steven, the third year generalist beginning teacher and Elizabeth, the school principal, were willing volunteers in the study.

Case study is an ideal methodology when a holistic, in-depth investigation is needed (Feagin et al., 1991). It is often used to examine individuals' "uniqueness and commonality ... their stories ... how they function in their ordinary pursuits and milieus" (Stake, 1995, p. 1) in order to gain "greater understanding of the case" (Stake, 1995, p. 15). Moreover, the phenomenon being researched is studied in its natural context, bounded by space and time (Hancock \& Algozzine, 2006). Subsequently, it can help to penetrate situations 
in "ways that are not always susceptible to numerical analysis" (Cohen et al., 2000, p. 181).

A narrative approach was employed with a focus on the beginning generalist teacher and the principal. Narrative approaches have investigated human phenomena in education (Clandinin \& Connelly, 2000), music education (Barrett \& Stauffer, 2009) and the developmental psychology of music (Barrett, 2009). As an epistemological approach, narrative inquiry seeks to understand human subjective experience by making people's stories a central focus of research (Connelly \& Clandinin, 1990; Clandinin \& Connelly, 2000; Clandinin, 2006, 2007). According to Barrett \& Stauffer (2009, p. 3), at "the simplest level narrative inquirers live and work alongside research participants in order to understand the ways in which individuals and communities story a life and live their stories".

The primary research products of a narrative inquiry are constructed or co-constructed accounts that re-present the participants personal and professional experiences (Clandinin \& Connelly, 2000). In this study, a story constellation narrative approach was utilised to move the interview data from a featureless text to a story. The story constellation approach attempts to locate teachers' knowledge in the multiple contexts within which it is created. According to Craig (2007, p. 6):

Constellations allow for school life to be characterized without the flattening or dismissing of teachers' and principals' knowledge and their relationships and interactions amid the flow of events in the educational enterprise ... [where] ... the constraints of both formalist and reductionist investigations are avoided.

The story constellations approach opens out in a three-dimensional space (Clandinin \& Connelly, 2000), and is comprised of: the temporal (past, present and future), the personal and social (interaction), and the contextual (situation and place).

In story constellations, narratives of experience relate to one another like 'nests of boxes' (Craig, 2007), that is, connected and enclosed within other elements. Their narratives of experience are always shifting, "each with a unique spiraling pattern, necessarily involving many plotlines, which, in turn, bring multiple meanings to bear on teachers' knowledge as shaped in their reforming school contexts" (Craig, 2007, p. 4). Through the engagement of this approach, a "... constellation of factors... including the moralities and mores of teachers" (Schwab, 1970, pp. 8-10) are brought to the surface for discussion and analysis.

The approach uses a paired story combination to bring to light factors unique to schooling contexts. Paired stories include stories of teacher/teacher stories; stories of principal/principal stories; stories of school/school stories; stories of curriculum/curriculum stories; stories of community/community stories (Craig, 2007). Teacher stories are stories told by teachers, whereas stories of teachers (the partner story) are stories told about teachers. Similarly, stories of school are stories given to schools, whereas school stories are stories told by schools. In the story constellation approach, Stories of community are the stories told about communities, whereas community stories are stories that communities tell. Stories of reform are stories told about school reform, whereas reform stories are stories educators tell about the human experience of how reform stories become lived in school contexts (Craig, 2007). The paired stories allow hidden themes within the individual and schooling culture to become known through human agency exhibited through the narrative

\section{CAMBRIDGE JDURNALS}


construction. The story constellation of the beginning generalist teacher and the principal is presented under each paired story heading in this paper.

The benefit of utilising a story constellation as a form of narrative inquiry is that those exposed to the story are often able to connect with and engage in the story in a direct way, relevant to their own experiences. This presents the possibility that "people are likely to be disturbed by it and the disequilibrium that ensue may lead to change", although this may not always be in a way that is predicted (Lincoln, 2003, cited in Craig, 2007 , p. 14). Accordingly, readers "may contribute to the dilemmas posed within the text" (Barone \& Eisner, 1997, p. 75). While there is no way to predict the outcome of this story constellation, it is hoped that it will stimulate the reader to consider ways in which to address the challenges currently impacting on the teaching and learning of music and the arts in schools in Queensland, Australia. It is hoped that readers question ideas that the story constellation reveals.

\section{Method and techniques}

An interview schedule was devised for the beginning teacher and his principal. It consisted of two semi-structured interviews lasting between 40 and 60 minutes. More than one interview was chosen to develop a relationship with the participant. The advantage inherent in this relationship is that interviewees come to better understand the value that researchers place on their participants" "experiences and points of view" (Kirkevold \& Bergland, 2007, p. 73). This relational understanding between researcher and participants is congruent with the philosophies at the heart of narrative inquiry (Clandinin \& Connelly, 2000). Interviews were recorded and transcribed. In addition, field notes about the physical description of the school were recorded. The field notes assisted in the development of a greater understanding of the context and in fleshing out the story constellations.

All field notes and transcripts were shared with participants as constructions of meanings were explored. Regular phone discussions, meetings and emails were made between the researcher and participants after the interview to continue co-constructing the story.

The data were searched for "chunks of interview text about particular themes", meaningful and relevant to the study, which figured "importantly and repeatedly" (Riessman, 1993, p. 67). As those in the narrative field know, analysis becomes an "increasingly complex" task, involving reading, and "relentlessly rereading", the field texts (interview transcripts and observational field notes) of both participants in order to "narratively code" the data (Clandinin \& Connelly, 2000, p. 131). The analysis became inductive (Janesick, 2000, p. 389) locating "narrative threads" or "story lines" interwoven and interconnected throughout the data sets (Clandinin \& Connelly, 2000, p. 131). The researcher began to see meaning in the field text. However, Clandinin and Connelly argue that no matter how compelling our narrative inquiry field texts are, we need to "fight against our desire to let [them] speak for themselves" (2000, p. 130; see also Gough, 2003 , p. 30). The researcher projects a space in which participants can construct or reconstruct with the research the salient meanings from their stories. Through an ongoing process of construction and reconstruction of meaning, field texts are able to be turned into publishable research texts (Clandinin \& Connelly, 1994), in this case in the form 
of a story constellation structured around Craig's (2007) paired stories, viz: stories of teacher/teacher stories; stories of principal/principal stories; stories of school/school stories; stories of curriculum/curriculum stories; stories of community/community stories.

After presenting the data as the paired stories, it is not uncommon in story constellation methodology to use metaphors to describe the relationship between stories (Craig, 2003, p. 191). In this study, rather than use metaphor, it was decided that value statements would be employed to capture the essence of the story. These are then carried through to the discussion section of the paper. In the paired stories that follow, italics are used to make clear the direct quotations from the research participants.

\section{School context}

The Birkdale Catholic Primary School is located in a relatively low socio-economic area on the outskirts of a large town in Queensland, Australia. Enrolments at the school are around 250 , however the school population is declining. The area around the school is populated by many elderly people, suggesting that the demand for schooling may have decreased. The school is also in close proximity to three state schools. One of the state schools is relatively new, with new buildings and resources.

In Australia, state and non-state schools are funded differently by the government. While the Birkshire Catholic Primary School receives some funding, the principal says the school does not have access to the Department of Education funded Instrumental Music Program. The Queensland Instrumental Program provides a comprehensive tuition programme in which students learn orchestral or band instruments through instruction on a group basis. Educational outcomes are maximised for all students, taking full account of individual circumstances such as their location, gender, socioeconomic situation, language and cultural background, and any impairment and special talents they may have (Department of Education, 1990).

All schools in Queensland are required to employ registered teachers who have qualified from a recognised teacher education programme. All Queensland schools are required to teach the eight key learning areas (maths, english, science, arts, technology, study of society and environment, health and physical education and language other than english) mandated by the Queensland Studies Authority.

A specialist teacher is employed part-time to take drama and music with each primary school class for an hour a week (an integrated music and drama lesson). There are no specialist teachers for the other areas of the arts. The generalist teachers in the school are still responsible for the majority of arts (dance, drama, music, visual arts and media) instruction and assessment in the classroom. The generalist teacher is expected to teach the arts as per the recommended guidelines (Essential Learning Statement, 2007) from the Queensland Studies Authority. Teachers are expected to assess skills and knowledge in music and the arts. In the guidelines music and the arts have standards that students are expected to achieve.

According to the principal of the Birkdale Catholic Primary School, the school has a good reputation for catering for children with special needs. Within the school population of 250 students, 26 (or approximately 10\%) are ascertained as needing intervention strategies for their learning.

\section{CAMBRIDGE JDURNALS}


Steven Matthews is a third-year teacher of a composite class of year six and seven students at the Birkdale Catholic Primary School. He has 25 students in his class. This is his first year here as a generalist teacher and he has also taken on the responsibility of organising physical education in the school. Previously, he has spent two years at a rural school where he was one of three teachers. He is happy to be in a bigger town.

Steven decided to become a generalist teacher because it was a good place to be. He suggests that this role allows him to mentor students and help them to pursue their goals and abilities. Well it definitely wasn't for money you know, he jokes. Steven's sense of humour begins to shine through. He admits that while at university he did not learn much about arts education. He suggests that the course was too short, with greater modelling needed by lecturers and supervising teachers for learning to teach music and the arts.

He adjusts the papers that are in front of him. Well to be perfectly honest the arts at uni[versity] was pretty much useless. They just tried to do too much in too short a time frame. I mean I don't think it gave me any more confidence to teach the arts than what I already had. I mean the course was okay, but there was just too much stuff in too little a time. There was more reading in arts teacher education than anything else. I actually found the school based stuff a lot more engaging in comparison to the actual theory in the subject. The modelling of the arts took place at school. I had a really good teacher back then. He was one of those arty, farty people that really acted it; you know doing stupid things. To be honest there is not enough Arts education in university. I mean they do have dedicated Arts teachers that go through university and do that as specialists, but for a generalist teacher that just does run of the mill everything there is not enough. But then saying that, where are you going to fit it in because there are just so many other things that uni[versity] has to go through. I mean a lot of it is rubbish and doesn't help you.

Steven breathes in slowly and looks around the room. He sits closer in his chair and speaks quietly. It is one of those things, if you don't use it, you lose it. I have definitely lost what I previously did. With my Visual Arts stuff, I definitely would not be able to do it now. If I had to cut out sections of a pot, I definitely couldn't do it. I've forgotten all those different things in Visual Arts. I guess also with the drawing side, if you don't practice it you are going to likewise. I guess it is similar to music. If you don't practice you get rusty. With music at university though I didn't get the basics.

"So do you engage with the Arts in your life now?", the researcher asks.

Well to be really honest, the only thing I could say is that I listen to music, especially when I am driving. I don't play it. I haven't done any drawing or painting in a long time, not since school really.

The researcher nods at Steven. "And do the students like arts in your classroom?"

I mean I think the kids enjoy arts activities but I've got some that are really bucking at the moment with the distorted drawing. But that's because they're perfectionist, ones who have to get it right. I've got other kids who couldn't be bothered but the majority of them are enjoying what's going on. He pauses, catching his thoughts before continuing. I did a free hand drawing of a person's face where they weren't allowed to look at the page and they weren't allowed to lift their hand. They had to draw the eyes and the ear, the general shape of the head, put some hair on it. They weren't allowed to lift their hand off the page so 
wherever they went next they had to draw the lines around it. Then they had to select three colours, be they hot or cold and they had to colour it in using those three colours ... I got the idea from a couple of years ago. It's just a really fun activity to do. The kids get involved in it. They look at their face and go 'yoy, yoy, yoy'! You can spot some kids who are hesitant to try things, because their pictures are just so darn tiny. Like little dots on a page. While other kids who are out there, their pictures are big enough to fill the page. To Steven, these students enjoyed arts activities and it allowed them to explore themselves in different ways.

Steven continues. I don't really teach music though. I don't know how. My students don't really learn music in my classroom.

"Do you consider yourself a teacher of the arts?" the researcher asks.

Well. Steven glances around the room before continuing ... I don't consider myself a teacher of the arts. Not even an artist. I've never gone any further with it than what I did. I have limited musical skills.

\section{Stories of principal/ principal stories}

Elizabeth has been the Principal of Birkshire Catholic Primary School for just over three years. Previously she had been a principal at another Catholic Primary School. She believes all students have a right to be provided with the best quality education possible, regardless of their socio-economic status. Elizabeth believes all the generalist teachers in her school should engage with music and arts activities in the classroom.

"So what do you think is the role of music and arts in education?", the researcher asks.

Elizabeth smiles. Well, the role of arts in education is really complementary to literacy and numeracy and a lot of skills in both of those areas can come from the arts. She moves her chair closer to her desk. But I think the most important thing is that it gives an area of outlet for children who are not academic to feel like, you know, "I can do this and I know I can do this well and there is nothing wrong with this'. Elizabeth inhales slowly. You know in Visual Arts you can't go wrong with your interpretation of a task set by a teacher. I think for some kids that's really important and they achieve success.

Elizabeth continues, talking about the benefits of learning a musical instrument. She'd love to see all children learn a musical instrument. At the Birkshire Catholic Primary School, the instrumental programme is funded by parents who can afford instruments and lessons. I mean unfortunately, even at our school, we have families who aren't able to afford it. I think some of the state schools have a great idea. I don't know if it happens in all state schools where it is just available for anybody and it is paid for within the school budget. It would be great if this could be extended to all schools across the nation. It is really valuable. I think the students learn to express themselves. I know that there is research that correlates learning and instruments and academic achievement. I think it can really teach students a lot of skills and also about themselves. They learn to focus on tasks and it is that idea that they perform to an audience.

Elizabeth pauses, gathering her thoughts. She continues, talking about problems with the perceptions of music and the arts and associated problems with formal assessment. Music and arts education are graded on an A-E scale in the school (as per government recommendations for reporting). She uses an example of parent understanding about music and the arts. Elizabeth describes that the status of a subject improves if there is formal

\section{CAMBRIDGE JDURNALS}


assessment. When a key learning area that has an assessment component to it, it probably brings the status of it up, whereas if it doesn't it devalues it in the eyes of some parents. We need to have assessment in music and the arts so parents feel it is valuable, but we have more flexibility for activities without assessment. So sometimes as a principal, you face an uphill battle of trying to get people to understand that music and the arts is an important part of child development.

Elizabeth considers herself an artist as she enjoys music, arts and crafts, especially crocheting, sewing and doll making. Her love for the arts appears to enter her teaching practice. She reflects on trying to include the arts as a teacher. I know that when I was a school teacher I tried to always place an importance on that. There was a programme I was running about 15 years ago. We used to use a lot of re-sourcing from the community. So I used to find out if there was anyone who had particular skills and there used to be a guy who came in and helped with music and dance. But I do love arts and craft. It is a part of who I am.

\section{Stories of school/ school stories}

At the Birkshire Catholic Primary School, the skills of generalist teachers are often drawn upon to help other teachers plan activities. According to Elizabeth, drawing on the talents of generalist teachers provides greater opportunities for all subject areas to be taught, especially if the school has limited access to specialist teachers. It was expected by the principal that generalist teachers at the Birkshire Catholic Primary School would share their knowledge with other teachers, making sure that all areas of all subjects were covered within the school curriculum. For example, Steven is in charge of sharing knowledge about physical education, while another generalist teacher organises visual arts activities.

Elizabeth also employs a specialist teacher to take each class for integrated drama and music lessons. Since the specialist teacher is only part time and on a contract, she does not appear to provide extra curricula activities for students such as choir.

I ask Steven about music. Well apart from their time with the specialist teacher for integrated music and drama, there isn't really much music that goes on in my classroom. I don't know what goes on in those lessons. I still have to try and teach and assess the arts myself somehow! I can't even understand the curriculum. The specialist teacher is only here for a few days a week. Who do I go to? She doesn't get paid to help me, only to teach so many classes.

\section{Stories of community/community stories}

The community within the Birkshire Catholic Primary School is called upon to help with learning experiences throughout the year. Elizabeth smiles as she describes the example of a visiting author. It is for stage two and stage three students. The programme is part of an initiative called 'Child Write Program'. The author visits the school one day a week and creates a book that becomes published. Various copies are placed in the community, including the local library and hospital. The students get such a thrill out of making the book together. This year we have also managed to book in an illustrator and she is going 
to work with stage three, our older children and hopefully some of our other children. So, I'm very excited about that. Oh yes and there is another example. There is the teacher aide who helps with dance. In previous years we have had a fairly large Sudanese population and last year we were allocated a Sudanese aide and she actually had a flair for hip-hop dancing. She used to take the kids once a week who were interested during morning tea time just to do a little bit of that. And, they presented on assembly on our parade area to the rest of the school

We also have instrumental performances from the children who learn an instrument. We also have sing-a-longs for events such as Christmas.

Elizabeth takes a sip of water. She puts the glass down. And I almost forgot the talent competition. There was a teacher who was teaching here a couple of years ago who started this up. She has since retired but comes back every year to run it for us. We have judges that the children nominate and they go for rehearsals and practice with the teacher, and then we have a day where they bring the judges in and all the school goes to watch. We do try and narrow it down, but we must admit the retired teacher's really generous and we sit there for a few hours watching. There are various categories - the dance category, instrumental music. There's a singing category and a drama category. The students who sing are amazing.

Parent involvement is strong. Parents and friends to the school will come in and help with different activities. They are a big help. Elizabeth admires all the community members who help with the music and arts extra curricula activities. I think we have support from everyone. I think the arts are an area that really lends itself to that, because like I said, a lot of teachers don't have the skills in some of those areas and I think the clever teacher tries to use what's around. And to really say, look I don't really know how to do that but I am sure I can find someone who can help me.

\section{Stories of reform/ reform stories}

The reform being played out on the professional knowledge landscape of the Birkshire Catholic Primary School is based on the National Assessment Program for Literacy and Numeracy (NAPLAN). This was a form of national standardized testing that was introduced in 2008 for year three, five, seven and nine students. Both Elizabeth and Steven discuss potential problems music and the arts will face as greater focus is placed on literacy and numeracy.

Elizabeth begins slowly. Her voice is softer. I think at the moment, what is happening on the national scene is very much driven by government agenda, we have these levels of skills and if you're not going to get that then sack the principal and teachers won't receive bonuses. It's that whole accountability. I think it is important but it shouldn't be to the detriment of other subjects including music and the arts. As an educator you see many students become very successful, but it's not always in the academic fields. I suppose I have a worry that if we are going down the line where everyone has to be over the benchmarks for literacy and numeracy, you're going to see the slide in some of the subjects like music, dance and drama. She pauses. Unfortunately there are just so many things thrust upon schools these days to have to deal with. One of the main ones is the social issues that

\section{CAMBRIDGE JDURNALS}


are happening. You know, times are tough and it is hard to find time for everything in the curriculum.

Also ... Well this probably isn't policy making but funding I think is really important, because with the arts, it needs a lot of funding. And I think to get the best out of kids you do need to have specialist teachers. The other thing is equipment. It's an area, I mean I suppose all subjects need equipment, but music like sport, if that was funded you need to make sure there is a decent amount for equipment. I think that's probably the crux of it good teaching and the ability of schools to resource areas of the curriculum appropriately. If policy makers were committed to music and the arts in schools, they would provide suitable funding and encourage quality teaching.

Steven echoes the same concerns of music and the arts disappearing in current reforms. There is a lot of pressure from curriculum reform. Nowadays you have to be able to do certain things to get certain jobs. You need to have certain things to get university degrees in those areas. I mean if you were doing a trade, there would be nothing wrong with you doing arts.

I would hate to see the music and the arts disappear in the current reforms because it is a relaxing thing for the kids and it is also something that is just out there. It is something that the kids can learn from other than just having to sit down and do the numbers and the writing and all of that.

Both Elizabeth and Steven suggest there are problems accessing professional development in music and the arts.

The researcher asks Steven if he feels supported with teaching music and the arts.

I don't feel supported at all from anyone outside of school. At this point in my career I am still open to learning about music and the arts though if they were available.

"So do you have support from the state government?" the research asks.

Steve laughs out loud. Yeah - no, definitely no!

"So who supports you in the teaching of music and the arts in your classroom?"

Me myself and I. I have one teacher who helps me but that is it.

"Anything from professional development organisations?" the researcher asks again.

He inhales and exhales slowly. If I knew of it I would take it. I would do courses if they were available but I haven't heard of anything. I haven't seen anything that has come through either. In the entire three years of my teaching, nothing.

"So what help would you like?"

Well, policy makers need to make it accessible for the dumb people like me. He laughs. The current syllabus is too verbose and difficult to understand. Something that is easy to lay my hands on, with easy hands-on activities, where I can look at it and go I know what you're speaking and looking for'. You know that type of thing. I'm one of those people who learn by seeing and doing, instead of being told. If I learn how to do it and can do it, I'm comfortable to be able to do it. He pauses briefly before continuing. I'd like to sit down and make something to get an idea of how long it takes, what it's about and where it comes from type of thing.

Elizabeth comments about the cost of professional development and the lack of music and arts professional development opportunities. She would like to have access to arts professional development, however the cost of courses would have to be low. More professional development courses these days just fund themselves out of cost so it's not 
feasible. I can't afford to send teachers. Even for general classrooms teachers looking to upgrade or looking to develop skills in particular areas, the professional development that is on offer across the board in some key learning areas fund themselves too high. The cost is enormous.

Elizabeth raises the idea of improved teacher education for music and the arts. She sits straight in her chair. I know that, and this was back in the dim dark ages when I went to uni[versity], I hadn't learnt a musical instrument, it just wasn't affordable to my parents at the time when I was growing up. I know we did things like recorder and xylophone and I know that really didn't do too much for me! You know I didn't pick music up much in the classroom at all to use as a tool. So it probably depends on the level of commitment by the uni[versity] to what they want people to come out with. I mean the attempt to do music while I was at uni[versity] hasn't helped me a great deal at all.

You know unless you do a really intensive course where by the end of it where if you've got an instrument that you want to learn that's not like the recorder. I don't know if they still do it - I just think the recorder is a bit of a 'band-aid' thing. Say if you've always had an interest in learning the guitar but you've not got around to it, I mean if you're prepared to put in the hours it takes than maybe, I don't know how they run that sort of thing, but that's what I mean about being a bit more fair dinkum about it I suppose. I've never seen a teacher take out a recorder to work with a class. Same with the xylophone. I've never seen a teacher take a one out and say - I'm going to do a music lesson now. I think learning the recorder is probably quite detrimental to a lot of teachers. I guess the teachers also need to have a passion. Teachers and the school must also be passionate.

The researcher thinks back to the interview with Steven in the staff room, recalling his similar views. His face tightens as he discusses improvements in teacher education.

I mean there are lots of areas that need improvement. I'd like to see more being done in front of me so that I could do something with it. There's not enough. There's not enough music and arts education in university. Like the one I went through, they stuck music and art together for one semester, and they did a part time basis on both where you went to music for six weeks, and then six weeks in art. I mean the amount of stuff that they went through, things like the history of arts, the different arts, the renaissance, the industrial revolution and all those things and how they affected arts. More hands-on activities. It needs to be extended over a couple of semesters. And remove those musical stupid things, what are they, they drive you insane. He begins to mime playing an instrument.

"Recorders?" I suggest.

Yes them. Steven laughs. They're horrible. Get rid of them.

\section{Discussion}

Story constellations are designed to engage the reader to consider the challenges being shared. In this study, the reader must consider for themselves the problems of teaching music and arts at this school context in Queensland Australia. From this may come the challenging of policy for arts education. To complete this paper, we will bring to light a few of the issues raised from this story constellation for the reader to ponder further.

\section{CAMBRIDGE JDURNALS}


Value 1: The arts at university was pretty much useless - they need to stop using band-aids in teacher education

The story constellation raises interesting questions about Steven's ability to teach music and the arts. He held low perceptions about his knowledge and skills in music. Steven is more comfortable teaching visual arts in his classroom, even though he is expected to teach all of the arts strands (music, dance, drama, visual arts and media). He positioned himself as a novice with the arts and was less inclined to teach arts education in his classroom. Activities that he did teach he had learned from other teachers or from his own personal experiences. Questions are raised about how to improve Steven's confidence to teach the arts. The principal concurs, commenting on the failure of pre-service teacher education and professional development to adequately prepare generalist teachers who are capable of including music and the arts in the classroom.

Value 2: At this school, arts education is the glue that binds the community

The power of the community was also made evident in this story constellation. At the Birkshire Catholic Primary School, interpersonal support was provided by the community members and other teachers who were drawn upon for extra curricula music and arts activities. Music and arts extra curricula activities had encouraged parents and community members to become actively involved. The extra curricula activities were run by the generalist teachers, not the music specialist. These activities appeared to move beyond classroom learning, to provide a sense of community for all. They were not part of school policy, were not part of the regulated content for the arts curriculum and were not assessed with grades.

Value 3: The arts is (should be) for everyone - you are going to see the slide of the arts

The gap between policy rhetoric that supports music and arts education and actual access to music and arts funding played out on the landscape at the Birkshire Catholic Primary School. The non-state school did not want this story, but was given this story because of funding issues and limited access to the Instrumental Music Program. The principal spoke of the inequity within instrumental music lessons in her school. While instrumental lessons were free at the state school up the road (funded by the Department of Education- the agency for state funded schools), they were not available at the Birkshire Catholic Primary School (Catholic schools are administered by regional Archdioceses). Parents had to pay full fees for instrumental lessons if they wanted their child to learn. Subsequently, many students were denied the opportunity to learn an instrument as they did not attend a state school. Elizabeth believed that all students should be given the opportunity to learn a musical instrument, regardless of the school type they attend. This form of inequity sends clear messages to the school community about the valuing of music and education in different school contexts.

These three values, along with others that might be evident to the reader of this paper, are drawn from the constellation generated out of the paired stories. While this above story constellation illuminates the teachers' unfolding contextualized experiences over time, 
the constellation does not produce "a script to be followed" (Davis Jr, 2003, p. 11). It is impossible to generalize from this one narrative informed case study about contexts, schools types, settings, teacher and principal belief's, teacher education programmes and professional development. However the constellation provides a snapshot of truth to the teller of that story. It operates in a Bakthinina spirit of novelness, where it may 'inspirit the readers to enter into dialogue with them' (Barone \& Eisner, 1997, p. 75). The narratives avoid the epic and grand narratives approach where the purpose is "to impart the final word, to shut out other voices, to close down interpretative options" (Barone \& Eisner, 1997, p. 75). Rather, story constellations are designed to make the reader think about responses for themselves, and to prompt the questions that need to be asked for arts education.

\section{Acknowledgement}

Findings in this paper are part of a $2010 \mathrm{PhD}$ thesis from the School of Music, University of Queensland. Susanne Garvis would like to thank her primary supervisor, Professor Margaret Barrett and secondary supervisors, Professor Donna Pendergast and Nan Bahr, for supporting this thesis.

\section{Note}

1 Beginning teachers are classified in Australia as in the first three years since graduation from a teacher education degree. In other countries they are known as 'novice' or 'early-career teachers'.

\section{References}

AUSTRALIAN GOVERNMENT (2008) National Review of Visual Education. Retrieved 2 April 2009 from $<$ www.dest.gov.au/...education/.../NRVE_Final_Report_pdf.htm >

BAMFORD, A. (2002) The Qualities of Primary Art Teachers. Unpublished PhD thesis, University of Technology, Sydney.

BAMFORD, A. (2007) Creativity Matters: The Arts in Early Years. London Borough of Ealing.

BARRETT, M. (2009) Sounding lives in and through music: A narrative inquiry of the 'everyday' musical engagement of young children's lives. International Journal of Early Years Education, 14 (3), 201-230.

BARRETT, M. \& STAUGGER, S. (2009) Narrative Inquiry into Music Education: Troubling Certainty. Dordrecht, the Netherlands: Springer.

BARONE, T. \& EISNER, E. W. (1997) Arts-based educational research. In R. M. Jaeger (Ed.), Complementary Methods for Research in Education (2nd edn). Washington: AERA.

BRUNER, J. S. (1987) Life as narrative. Social Research, 54, 11-32.

CLANDININ, D. J. (2006) Narrative inquiry: a methodology for studying lived experience. Research Studies in Music Education, 27, 45-55.

CLANDININ, D. J. (Ed.) (2007) Handbook of Narrative Inquiry. London: Sage.

CLANDININ, D. J. \& CONNELLY, F. M. (2000) Narrative Inquiry. San Francisco: Jossey-Bass.

COHEN, L., MANION, L. \& MORRISON, K. (2000) Research Methods in Education (5th edn). London: Routledge.

CONNELLY, F. M. \& CLANDININ, D. J. (1990) Stories of experience and narrative inquiry. Educational Researcher, 19 (5), 2-14.

CRAIG, C. (2007) Story constellations: A narrative approach to situating teachers' knowledge of school reform in context. Teaching and Teacher Education, 23 (2), 173-188.

\section{CAMBrIDgE JDURNALS}


CRITES, S. (1975) Angels we have heard. In J. B. Wiggins (Ed.), Religion as Story (pp. 23-63). Lanham, MD: University Press of America.

DAVIS, O. L. Jr. (2003) Foreword. In C. J. Craig (Ed.), Narrative Inquiries of School Reform. Storied Lives, Storied Landscapes, Storied Metaphors. Greenwich, CT: Information Age Publishing.

DEPARTMENT OF EDUCATION (1990) Designing an Instrumental Music Program. Retrieved 2 June 2009 from <http://education.qld.gov.au/strategic/eppr/curriculum/crppr006/curriculumguide.pdf>

DEPARTMENT OF EDUCATION, SCIENCE AND TRAINING AND CENTRE FOR LEARNING, CHANGE AND DEVELOPMENT (2005) National Review of School Music Education: Augmenting the Diminished. Retrieved online on 27 September 2007 from <www.dest.gov.au/sectors/school_education/ publications_resourcces/profiles/school_Music_education.htm.>

FEAGIN, J., ORUM, A. \& SJOBERG, G. (Eds.) (1991) A Case for Case Study. Chapel Hill, NC: University of North Carolina Press.

GARVIS, S. (2010) An investigation of beginning teacher self-efficacy for the arts in the middle years of schooling. PhD Thesis. Brisbane: University of Queensland.

GARVIS, S. \& PENDERGAST, D. (2010) Supporting novice teachers of the arts. International Journal of Education \& the Arts, 11 (8). Retrieved from http://www.ijea.org/v11n8/.

HANCOCK, D. R. \& ALGOZZINE, B. (2006) Doing Case Study Research: A Practical Guide for Beginning Researchers. New York: Teachers College Press.

HENNESSY, S., ROLFE, L. \& CHEDZOY, S. (2001) The factors which influence student teachers' confidence to teach the Arts in the primary classroom. Research in Dance Education, 2 (1), 53-71.

HENRY, C. \& LAZZARI, M. (2007) Changing teacher preparation in art education. Art Education, 60 (1), 47-51.

JANESICK, V. (2000) The choreography of qualitative research design: minuets, improvisations, and crystallization. In N. K. Denzin \& Y. S. Lincoln (Eds.), Handbook of Qualitative Research (2nd edn., pp. 379-400). Thousand Oaks, CA: Sage.

KIRKEVOLD, M. \& BERGLAND, A. (2007) The quality of qualitative data: issues to consider when interviewing participants who have difficulties providing detailed accounts of their experiences. International Journal of Qualitative Studies on Health and Well-Being, 2 (2), 68-75.

MINISTERIAL COUNCIL ON EMPLOYMENT, EDUCATION, EARLY CHILDHOOD, DEVELOPMENT AND YOUTH AFFAIRS (1989) Hobart Declaration on Schooling. Retrieved 6 December 2009 from <http://www.mceecdya.edu.au/mceecdya/hobart_declaration,11577.html>

MINISTERIAL COUNCIL ON EMPLOYMENT, EDUCATION, TRAINING AND YOUTH AFFAIRS (1999) Adelaide Declaration on Schooling. Retrieved 3 October 2007 from <www.mceetya.edu.au/ adeldec.htm>

MINISTERIAL COUNCIL ON EMPLOYMENT, EDUCATION, TRAINING AND YOUTH AFFAIRS (2005) National Education and the Arts Statement. Retrieved 27 January 2007 from <http://www.curriculum. edu.au/verve/_resources/National_Education_Arts_Statement.pdf>

MUSIC COUNCIL OF AUSTRALIA (2003) National Report of Trends in School Music Education Provision in Australia. Sydney: MCA.

ORECK, B. (2001) The Arts in teaching: An investigation of factors influencing teachers' use of the Arts in the classroom. Doctoral dissertation, University of Connecticut, Storrs.

ORECK, B. (2004) The artistic and professional development of teachers: a study of teachers' attitudes toward and use of the arts in teaching. Journal of Teacher Education, 55 (1), 55-69.

QUEENSLAND STUDIES AUTHORITY (2007) Arts Essential Learnings Years 1-9. Brisbane: QSA.

RIESSMAN, C. K. (1993) Narrative Analysis. Newbury Park, CA: Sage.

RUSSELL-BOWIE, D. (1993) Policy and practice in music education in NSW State primary schools. Unpublished PhD thesis, University of Wollongong, NSW, Australia.

RUSSELL-BOWIE, D. (2004) Arts education: are the problems the same across five countries? Paper presented at the Australian Association for Research in Education, 2004, Melbourne. 
SCHWAB, J. (1970) The Practical: A Language for Curriculum. Washington, DC: National Education Association.

SEIDMAN, I. E. (1991) Interviewing as Qualitative Research. New York: Teachers College Press.

SENATE ENVIRONMENT, RECREATION, COMMUNICATIONS AND THE ARTS REFERENCES COMMITTEE (1995) Arts Education. Canberra: Commonwealth of Australia.

SMITHRIM, K. \& UPITIS, R. (2001) Strong poets: teacher education and the Arts. Journal of Professional Studies, 9(1), 19-29.

STAKE, R. E. (1995) The Art of Case Research. Thousand Oaks, CA: Sage.

STEVENS, R. (2000) 'Where are we twenty years on?' - Review of Australian Music education research for the period 1978-1997. Research Studies in Music Education: Fostering Music Education Research Internationally, 14, 61-75.

STEVENS, R. (2003) Trends in School Music Education Provision in Australia. Sydney: The Music Council of Australia in collaboration with the Australian Society for Music Education and the Australian Music Association.

UNITED NATIONS EDUCATIONAL, SCIENTIFIC AND CULTURAL ORGANISATION (2006) Road Map for Arts Education World Conference on Arts Education: Building Creative Capacities for the $21^{\text {st }}$ Century. Lisbon, Portugal, 6-9 March, 2006. Retrieved online on 2 November 2007 from <http://portal.unesco.org/culture/es/ev.php-URL_ID=30335_DO-DO_TOPIC\&URL_SECTION= 2a.html.>

WINNER, E. (2007) Visual thinking in arts education: homage to Rudolf Arnheim. Psychology of Aesthetics, Creativity and the Arts, 1, 25-31.

\section{CAMBRIDGE JDURNALS}

